\title{
The Australian National University
}

From the SelectedWorks of Robert Cribb

1989

\section{De HAMOTs van Luitenant Koert Bavinck: het bendewezen van Jakarta in dienst van het Nederlands gezag (1947-1949)}

Robert Cribb, The Australian National University 


\section{MEDEDELINGEN \\ van de \\ SECTIE MILITAIRE GESCHIEDENIS \\ LANDMACHTSTAF}

Deel 12

's-Gravenhage, 1989 

Redaktie : drs P.H. Kamphuis (eindredacteur)
drs P.M.H. Groen
drs J. Hoffenaar
drs H.W. van den Doel (secretaris)

Redaktie-adres: $\quad$ Sectie Militaire Geschiedenis Landmachtstaf

Frederikkazerne, gebouw 103

Van der Burchlaan 31,

2597 PC 's-Gravenhage

Niets van deze uitgave mag worden verveelvoudigd en/of openbaar gemaakt door middel van druk, fotokopie, microfilm of op welke wijze ook zonder de voorafgaande schriftelijke toestemming van de uitgever. De meningen en opvattingen die in de desbetreffende auteur. Zij keven zijn en blijven voor de verantwoordelijkheid van de

No part of this book may be reproduced in any form, by print, photoprint, microfilm or any other means, without written permission from the publisher. The views expressed in this publication are those of the author and do not necessarily reflect the views of the Minister of Defence.

(c) 1989 by the Historical Section of the Royal Netherlands Army, The Hague,
Holland. Printed in the Netherlands. 


\section{INHOUD}

blz.

J. Verhoog

De werving van Westafrikanen voor het NederlandsIndische leger, 1831-1872

H.W. van den Doel De ontwikkeling van het militaire bestuur in Nederlands-Indië. De officier-civiel gezaghebber, 1880-1942

M.M. Hegener

De guerrilla op Midden-Celebes in 1942

\section{R.B. Cribb}

De HAMOTs van luitenant Koert Bavinck. Het bendewezen van Djakarta in dienst van het Nederlands gezag, 1947-1949

F. Imandt

'De onverbloemde waarheid'. De interne voorlichting aan militairen over Indonesië, 1945-1950

G. van Boom

De totstandkoming van de defensiegrondslagen van Nieuw-Guinea, 1950-1954

P.M.H. Groen

De eindafrekening: militaire resultaten van de tweede politionele actie

Uit de archieven

Boekbesprekingen

Biografische gegevens auteurs 


\section{De HAMOTs van luitenant Koert Bavinck. Het bendewezen van Djakarta in dienst van het Nederlands gezag, 1947-1949}

\section{R.B. $C r i b b$}

\section{Inleiding}

De rol die inheemse troepen hebben gespeeld bij het handhaven van het Nederlands gezag in het vroegere Nederlands-Indië is een nog tamelijk onontgonnen onderzoeksterrein. Dit geldt ten aanzien van de inheemse soldaten van het Koninklijk Nederlands Indisch Leger (KNIL), maar nog meer voor de hulptroepen die onder verschillende vaandels in dienst van het Nederlands-Indisch gezag hebben gevochten. Zo hadden vorsten van Midden-Java in de negentiende eeuw hun eigen militaire korpsen, waarvan het Legioen Mangkoenegaran het bekendste is, bestonden er zogenaamde barisans op Madura en waren er ook in de buitengewesten inheemse hulpkorpsen. Het gebruik van inheemse hulptroepen beperkte zich niet tot het (vroeg-) koloniale tijdperk. Ook in de revolutionaire jaren 1945-1949 speelden Indonesiërs een rol in het KNIL en in de veiligheidsbataljons die uiteindelijk bescherming zouden moeten gaan bieden aan deelstaten, zoals de Negara Pasoendan in West-Java en de Negara Sumatra Timoer in Oost-Sumatra. Er bestonden ook ondernemingswachten ter bescherming van westerse bedrijven en ondernemingen vooral op Java. De prestaties van de veiligheidsbataljons en de ondernemingswachten lieten in sommige streken te wensen over. Dat geldt echter niet voor het optreden van een dergelijke, nogal onbekende groep, de zogenaamde HAMOTs (Hare Majesteits Ongeregelde Troepen). De HAMOTs waren toegevoegd aan het $3 \mathrm{e}$ bataljon van het 9e Regiment Infanterie van de Koninklijke Landmacht (3-9 RI) en traden op het platteland ten oosten van Batavia/Djakarta op in 1947 en 1948 .

3-9 RI kwam eind oktober 1946 in Indonesië aan als onderdeel van de rede van koningin Wilhelmina op 6 december 1942 (7 december in Indonesië wegens het tijdverschil), waarin een staatkundige hervorming van het Koninkrijk der Nederlanden na de oorlog werd beloofd. Het bataljon werd aanvankelijk voor garnizoenstaken in Tangerang, ten westen van Batavia, ingezet, maar na een paar maanden werd het overgeplaatst naar Klender, een stadje aan de grote spoorlijn in de oostelijke ommelanden van Batavia. Daar kwamen de Nederlandse troepen voor het eerst in contact met het beruchte bendewezen van de Djakartaanse ommelanden.

\section{Djakartaanse jago}

Wie vandaag de dag met de trein naar Bandoeng reist, merkt niets van Klender. Het stadje is opgegaan in Djakarta, en men ziet niets anders dan lage, betegelde gebouwen, kleine fabrieken, stapelplaatsen van hout-, bamboe- en betonhandelaars en dergelijke. In $1946 \mathrm{zag}$ het er heel anders uit. Er was nauwelijks industrie behalve een spoorwegreparatieplaats, en het dorpje stond volkomen los van Batavia en werd door rijstvelden en kleine tuinen omgeven. Het makte deel uit van de zogenaamde particuliere landerijen. Deze landerijen waren al sinds de zeventiende en achttiende eeuw privébezit geweest van Chinezen en Europeanen. Deze hadden die gebieden van de Verenigde Oostindische Compagnie gekregen als blijk van waardering of van de Compagnie gekocht voor aanzienlijke bedragen. Bijna het gehele platteland van Tangerang tot en met Indramajoe met uitzondering van steden zoals Batavia en 
Krawang, werd in de achttiende eeuw als particulier eigendom uitgegeven. In tegenstelling tot elders op Java en Madoera, hadden de tuan tanah (landheren) niet alleen grondbezitrechten, maar ook quasi-feodale rechten op de inwoners van hun landen. De inheemse bevolking moest namelijk geen belastingen en herendiensten leveren aan de koloniale staat, maar rechtstreeks aan de landheer. Zij moesten bijvoorbeeld toestemming van de landheer verzoeken, en daarvoor betalen, om hun eigen velden te oogsten; deze toestemming werd nooit uitgereikt voordat de boeren de oogst van de tuan tanah hadden binnen gehaald. De landheren waren daarentegen verantwoordelijk voor het onderwijs en andere sociale voorzieningen op de landerijen. Over het algemeen kwamen zij echter hun verplichtingen niet na. Analfabetisme en ziekten heersten in het gehele gebied. De enige uitzonderingen waren een klein aantal grotere landerijen zoals de Britse Pamanoekan- en Tjiasemlanden (P. \& T. Landen) bij Soebang en de Nederlandse Michiels-Arnold-landen bij Tjibaroesa, die in zekere zin agribusinesses waren en op zijn minst zorg hadden voor de gezondheid van hun arbeiders. ${ }^{1}$

Van gewestelijk bestuur was geen sprake. De formele macht in de landerijen was geheel in handen van de landheren en de door hen aangestelde toezichthoudende macht. Deze landheren hadden echter noch de wil noch de vermogens een volledige politiemacht op te richten. Dientengevolge werd het gebied mede beheerst door machtige inheemse gevechtsgroepen, 'rampokbenden' genoemd. ${ }^{2}$ De leiders van deze benden werden jago (vechthanen) genoemd. Dat waren lieden die een vooraanstaande positie in de inheemse samenleving innamen, vanwege hun fysieke vermogens, bijvoorbeeld op het terrein van de pencak silat (het inheemse vechten) of hun capaciteiten in het schemergebied van het bovennatuurlijke. Vele jago pretendeerden namelijk door middel van amuletten of rituelen de onkwetsbaarheid, onzichtbaarheid of onhoorbaarheid van hun volgelingen te kunnen garanderen. Anderen pretendeerden zich zo nodig in een tijger of jakhals te kunnen veranderen. Deze vermogens gebruikten zij om een bende om zich heen te verzamelen, die zich voornamelijk toelegde op diefstal, maar zich ook aan moord en brandstichting bezondigde. Ten dele deden zij dit ten eigen bate, ten dele als een soort primitief volksverzet tegen de uitbuiting en de wreedheden van de tuan tanah. De bevolking zag namelijk in de benden het enig mogelijke tegenwicht tegen de mandoers en mantri's van de landheren. Een jago vestigde zich meestal in een dorp, waaraan hij een zekere mate van bescherming gaf, zowel tegen de landheren als tegen andere benden. Hij gaf ook regelmatig zijn buit aan zijn volgelingen en aan de dorpsbewoners, zowel om de loyaliteit van deze mensen te behouden of te versterken als om dergelijke materiële goederen kwijt te raken. Een jago moest namelijk altijd bereid zijn snel uit te wijken en teveel buit kon hem daarbij belemmeren. Het was voordeliger de overtollige buit te verdelen om sterke banden met de bevolking op te bouwen.

Sinds de jaren twintig van deze eeuw hadden de bendeleiders van de Bataviase ommelanden al regelmatig contact met de nationalistische stromingen ter stede. Beide groepen waren immers tegenstanders van het Nederlands gezag en konden elkaar op verschillende manieren helpen. De benden konden de nationalisten niet alleen nauwere contacten met de bevolking, maar ook een zekere mate van gewapende hulp bieden; de nationalisten konden daar een rooskleuriger toekomst voor de bendeleiders tegenover stellen. Het gewone lot van een bendeleider in de ommelanden was immers bijna altijd een gewelddadige dood. Door hun samenwerking met de nationalisten konden zij de hoop koesteren om het uiteindelijk tot dorpshoofd of even-

Zie verder: L. Castles, 'The ethnic profile of Djakarta', Indonesia III (1967) 153-204.

2 Deze beschrijving van het bendwezen van Djakarta is grotendeels gebaseerd op interviews met voormaIige lasykar in Indonesië in de periode 1982-1983. 
tueel tot politiefunctionaris te brengen. De sterke oppositie van de bendes tegenover
de landheren vloeide namelijk gedeeltelijk voort uit het volkomen gebrek aan moge-
lijkheden voor de bendeleiders om De bendes namen daarom deel aan langs legale weg hun sociale positie te verbeteren. in Batavia in november 1926. aan de opstand van Partai Komunis Indonesia (PKI) die in Bantam (1926) en West-Sumatra opstand was overigens van minder belang dan een poging gedaan vrijden. Ook tijdens de Japanse bezetting kregen sommige jonge nationalisten te beJapan gesteunde massaorganisaties.

\section{Haji Darip en de Republiek Indonesië}

Toen in augustus 1945 de Indor

benden' een van de belangrijkste gewapende uitbarstte, vormden deze 'rampok-

blik Indonesia. Een van de belangrijkste gewapendengen aan de kant van de RepuIndonesia (BARA) werd in Klender opgericht gewapende eenheden, de Barisan Rakyat de kleine Japanse militaire macht in het gebied een zekere Haji Darip. Nadat hij omdat Darip fel antigen fiefdom. Dit gebied gold weliswaar als Red uitgeschakeld, omdat Darip fel anti-Nederlands was, maar Darip achwaar als Republikeins gebied, lijk verenigen de Republikeinse leiders in Djakarta. Hij ken zich niet of nauwelijks gehield in dat de met de zogeheten diplomasi-politiek van de Republich maar moeiheden, met de Republiek zich zou aanpassen aan de belangen Groot-Brittaname de Verenigde Staten die de economischen van de grote mogenddienst in Z Zinnie,, dat, met zijn geallieerde troepenmache wereldmacht bezaten, en list besch huidoost Azië uitmaakte. Dit beleid werd door aanvankelijk de militaire ook schouwd als verraad aan de idealen van de door menig Indonesisch nationaook was bedoeld om een eind te maken aan de onafhankelijkheidsstrijd, die juist grote spoor zelf al lang een vooraanstaande jago, die zelfs inmenging in Indonesië. Nederlandwegstaking van 1923. Dat er een diplomatieke deel had genomen aan de oplossing zou helijk zou zijn, achtte hij uiterst onwaarschijnlijk van de strijd met g of niet, persoonlijk ook weinig voordeel opleveren kansen vergroten.

Darips ontevre als zijn persoonlijke winstjongere nationalisten die onder invloed steinse beleid werd gedeeld door een groep november 1945 hadden zij samen een eigen van de linkse leider Tan Malaka. In Djakarta Raya (LRDR/Volksmilitie van Groot-Djakatie opgericht, de Lasjkar Rakjat haar tenten op in Kecember 1945 door de geallieerden bezet en Djakarta als Klender Met verschill in Krawang, ongeveer tachtig kilometer bezet en de LRDR sloeg toen in 1945 en 1946 , in gevechtskracht sterk uiteenlopende oesten van de hoofdstad. niet alleen weerstand aan de geallieerde eenheden bood de LRDR en de regering van minis voerde zij ook een felle strijd tegen de diplom aan het oostvan minter-president Sutan Sjahrir tegen de diplomatiepolitiek die de grote Indonesischan akan hancurkan Republik Indonesia Raya stond de naam zijnen niet allonesische Republiek zal vernietigen'). Deze strijd Raya ('Ik ben degene LRDR belemmerde bijgenaam, maar ook schadelijk voor de onderhan Sjahrir en de de Nederlandse bijvoorbeeld de evacuatie van de voor de onderhandelingen. De zich ook niet aan de en krijgsgevangenen uit het Republikeinse gers geïnterneeroktober 1946 werd vooral het Republikekondigd. Vanaf medio 1946 was de Republikeinden die half 
Zo sterk was de tegenstelling tussen de Indonesische leger- en lasykar eenheden in het Krawangse in de tweede helft van 1946 dat enkele onderdelen van de LRDR, in het bijzonder die van Haji Panji, schoonzoon van Haji Darip, besloten de demarcatielijn over te steken en weer in het Klenderse te gaan opereren. Een tweede reden voor deze beslissing was dat Panji geen goede machtsbasis had kunnen opbouwen in het Krawangse, omdat dat gebied al overstroomd was met allerlei gewapende benden. Het oversteken van de demarcatielijn door Panji's bende vond plaats in januari 1947. De bende moest vervolgens hard optreden om zijn voormalige 'onderdanen' in het Klenderse weer in de hand te krijgen. Dit geschiedde op de gebruikelijke wijze door nationalistische propaganda, alsmede door moord, brandstichting en bedreigingen, gericht tegen diegenen die toch met de Nederlanders wilden samenwerken. Met name door de Nederlanders benoemde dorpshoofden moesten het ontgelden. Regelmatig verdwenen zij, dat wil zeggen, zij vluchtten of werden ontvoerd en/of door de lasykar vermoord. ${ }^{3}$

De (te) kleine Nederlandse troepenmacht in het Klenderse had eind 1946 en begin 1947 de grootste moeite om Panji en de zijnen uit te schakelen. Eerst werd geprobeerd Panji in handen te krijgen door een premie van $f 500$,op zijn hoofd te zetten. Toen dat niet lukte, werd in maart 1947 besloten om de Nederlandse troepenmacht aldaar te versterken met eenheden van 3-9 RI.

\section{3-9 RI en de oprichting van de HAMOTs}

Toen 3-9 RI eind oktober 1946 in de haven van Tandjong Priok aankwam, was de Republiek nog aan het onderhandelen met de Nederlandse Commissie-Generaal in het bergstadje Linggadjati. Een maand later parafeerden beide delegaties een ontwerpovereenkomst. Indonesië zou verdeeld worden in een drietal deelstaten (negara), te weten de Negara Kalimantan (Borneo), de Negara Indonesia Timoer (de voormalige Grote Oost), en de Republiek Indonesia (Java en Sumatra). Indonesië zou dan op korte termijn haar onafhankelijkheid krijgen als een federale staat, zij het binnen een Nederlands-Indonesische Unie. Aan Nederlandse conservatieve kant werd de Linggadjati-overeenkomst bepaald niet toegejuicht. Men achtte het te ver gaan de Republiek als verantwoordelijke, de facto soevereine mogendheid te erkennen. Aan Republikeinse kant beschouwde de overgrote meerderheid van de bevolking de overeenkomst als een ramp: de onafhankelijkheid waarvoor zij ruim een jaar had gevochten werd versnipperd en uitgesteld.

Voor 3-9 RI was het verblijf in Tangerang (november 1946 - maart 1947) een opleidingsperiode geweest. Zijn eerste echte oorlogservaring deed het bataljon op in het Klenderse. Ondanks een eerste gewenning en aanpassing aan de Indonesische strijdwijze, verontrustte de toestand in Klender het bataljon sterk. In het stadje zelf was er geen sprake van gewapend verzet, maar daarbuiten had het Nederlandse gezag nog nauwelijks betekenis. Als Nederlandse militairen patrouille liepen op het platteland werd hun opmars begeleid met lichtflitsen en trommelslagen ter waarschuwing van de bevolking en eventuele lasykar eenheden in de buurt. In plaats van de ontvluchte en vermoorde pro-Nederlandse dorpshoofden was er een Republikeins

3 Territoriaal Ondercommando Batavia aan C-cdiv, 18 februari 1947, in: Ministerie van Defensie, Centraal Archievendepot 's-Gravenhage (CAD), Archief van het Hoofdkwartier van de Generale Staf van Nederlands Oost-Indië (HKGS NOI), GG 6 (1947) 117; Oorlogsdagboek, staf inlichtingenrapport, 12 mei 1947, in: CAD, Archief van de staf van de 2e Inf. Brig. Groep, GG 7. 
chaduwbestuur, waardoor het bataljon bijna geen inlichtingen kon krijgen. ${ }^{4}$ Botsingen kwamen niet vaak voor, want de lasykar gebruikten de bossen, moerassen en malle wegen om gevechtsaanrakingen met de Nederlandse troepen te vermijden. De lasykar zelf noemden dat het systeem lumpur (moddersysteem): met laarzen kan men zich door de modder verplaatsen en als de laars wordt weggetrokken dan sluit de modder zich weer.

In het ontwikkelen van een effectieve tactiek tegen deze guerrilla speelde de bataljonsinlichtingenofficier, de tweede luitenant (KL) Koert Bavinck een belangrijke rol. Bavinck was al vóór de oorlog in Indië geweest, sprak wat Maleis, en had tijdens de Tweede Wereldoorlog enige ervaring met ondergrondse acties opgedaan in het Nederlandse verzet. Als inlichtingenofficier was hij doordrongen van de noodzaak om regelmatig betrouwbare inlichtingen te krijgen van de inheemse bevolking. Daarvan zou echter geen sprake kunnen zijn zolang de bevolking bloot stond aan het optreden van de lasykar. De veiligheid van de informanten moest absoluut kunnen worden gegarandeerd. Bavinck richtte daarom in Klender een rapid response team op, bestaande uit een tiental bekwame militairen. Deze inlichtingenactiegroep was zo georganiseerd dat zij onmiddellijk kon reageren op elk bericht van lasykaractiviteit, zowel 's nachts als overdag, zelfs tot in de meest geïsoleerde uithoeken van het Klenderse. Het team was er trots op dat het twee minuten na een bericht al per jeep kon uitrukken. Zo'n kleine eenheid kon geen grote lasykareenheden uitschakelen, maar zij kon wel weerstand bieden tot er Nederlandse versterkingen ter plekke waren gearriveerd. Om de Nederlandse greep op het platteland te versterken, werden ook kleinere eenheden van het bataljon geplaatst in buitenposten in het gebied, waar vandaan zij snel konden reageren op gebeurtenissen. ${ }^{5}$

Deze contra-guerrilla tactiek wierp goede vruchten af. Steeds meer inlichtingen over de activiteiten van Panji c.s. kwamen binnen en steeds meer leden van de lasykareenheden werden gevangen genomen. Het Klenderse werd langzaam maar zeker veiliger voor Nederlands-gezinden en onveiliger voor zowel de lasykar als voor het Republikeinse schaduwbestuur. Bavinck liet zelfs in april enkele gevangen lasykar op proef vrij, zowel als bewijs van de machtspositie van de Nederlandse troepen, als om hen gelegenheid te geven hun voormalige collega's te bewegen zich aan de Nederlanders over te geven. Door het toenemend aantal deserties en arrestaties werd de situatie eind april 1947 voor Panji kritiek. Omdat de macht van de Djakartaanse bendeleider taande, liep hij het risico dat ook zijn resterende volgelingen zich van hem zouden afkeren. Om zijn eigen positie nog zo goed mogelijk te handhaven, kon hij niet veel anders doen dan zich overgeven. In het geheim nam hij contact op met Bavinck. Bavinck beloofde hem dat als hij zich overgaf hij noch zijn volgelingen aan het departement van Justitie in Batavia zouden worden overgedragen. Op 8 mei 1947 werd Panji tenslotte in Batavia gearresteerd door de Nederlandse Inlichtingendienst (NEFIS) en aan Bavinck overgedragen. In de daarop volgende dagen meldden de resterende leden van zijn bende, op een paar uitzonderingen na, zich bij het kampement van 3-9 RI in Klender.6

4 Territoriaal Ondercommando Inlichtingendient, Gegevens Oostfront, 2 februari 1947, in: Algemeen Rijksarchief (ARA) 's-Gravenhage, Archief Procureur-Generaal bij het Hooggerechtshof van ( in: CAD. Groep, GGl2; Interview met Luitenant-kolonel b.d. K. Bavinck, 's-Gravenhage, 14 februari 1984.

Div, in: CAD Archief staf 2e Inf. Brig. Groep, GG8 map IV, bijlage 5 Oorlogsdagboek staf 2 e Inf Brig I Div, in: CAD Archief staf 2 ,

37; Interview met luitenant-kolonel b.d. K. Bavinck, 's-Gravenhage, 14 februari mei 1947, in: CAD, Archief staf 2e Brig. Inf. Groep, GG 8 map IV bijlage 37. Interview met luitenantkolonel b.d. K. Bavinck, 's-Gravenhage, 14 februari 1984; Oorlogsdagboek 3-9 RI, april-mei 1947, in: CAD, Archief staf $2 \mathrm{e}$ Inf. Brig. Groep, GG 12.

72 
Dit succes stelde het bataljon echter voor flinke problemen. De gevangen lasykar, te zamen gebracht in een kampement bij Kampoeng Soemoer, konden
niet zo maar worden vrijgelaten, gezag weer zouden gaan bestrijden of gevreesd werd dat zij dan het Nederlandse konden echter ook niet als krijgsgevangenen waren geen leden van het Republikeinse Nederland als krijgsmacht werd erkend leger, dat trouwens niet officieel door mede vanwege de hoop de desertie belofte van Bavinck, alsverstandig om hen gewoon aan de civiel-rechterlijk moedigen, leek het ook onGewone internering in het kam de civiel-rechterlijke autoriteiten over te dragen. leek evenwel behalve een kostbare ten in een kampement zouden de ook een weinig adequate oplossing. Opgesloden. ${ }^{7}$

Een gedeeltelijke oplossing voor deze problemen vond lasykar in de loop van mei onder zijn deze problemen vond Bavinck door de nen te gebruiken. Toen on spionandere doeleinden in te schakelen. Gesprekk het idee om de lasykar ook voor ten Bavinck duidelijk dat zij de over de demarcatielijn had de Republiek verafschuwden. Sinds hun oversteek Linggadjati-overeenkomst getek Republiek in maart 1947 de reeds geparafeerde als verraad, een teken van machtelo lasykar beschouwden die overeenkomst van haar totale ondergang. De lasykar die van de Republiek en een voorteken oog hielden, waren echter ook gekant die hun eigen belang altijd scherp in het dat daardoor hun sociaal-eck gekant tegen de Linggadjati-overeenkomst, ombliek verslechterden. Hun vijandigheid toekomstperspectieven binnen de Repugenomen na hevige botsingen in tegenover de Republiek was nog meer toeonder bevel van de Republikeinse comril 1947 tussen Republikeinse legereenheden en de Lasykar Rakyat Djakarta commandant in West-Java, kolonel A.H. Nasution, en het leger sloeg de lasykar vervolgen in Krawang. Krawang werd gebombardeerd dens die acties, maar wel werd hierdor uiteen. Veel lasykar sneuvelden er niet tijbroken. ${ }^{8}$ acties, maar wel werd hierdoor de macht van de LRDR voorlopig ge-

voormalige colle snel het gerucht door West-Java van een massamoord op lasykar, van lasykar op het Krawang van dasykar van Panji. De oude onderlinge concurrentie Klender nam de rancune tegenover de Republiek toten en in het kampement bij

Nog aantrekkelijker tegenover de Republiek toe.

ken van het leger van een West-Jasykar was het perspectief om deel uit te gaan maNederlands-Indische regering -Javaanse deelstaat, de Negara Pasoendan. Hoewel de voor een teruggave van de zich in de Linggadjati-overeenkomst had uitgesproken waren enkele vooraansta afspraak uit te voeren. Met medanders in West-Java geenszins geneigd om die R.A.A.M.M. Soeriakartalegawa, ontwierpen zij van de oud-regent van Garoet, in West-Java, gebaseerd op plan om een negara te stichten In 1948 is er zelfs nog sprake geweest eigen culturele identiteit van de Soendanezen. was dat een dergelijke negara over haar van een onafhankelijk Pasoendan. Duidelijk beschikken. De lasykar van Panji waren eigen gewapende macht zou moeten kunnen erop dat zij als min of meer bekwame militail geen Soendanezen, maar zij hoopten 7 Oorlogsdagboek 3-9 RI, juni 1947, in: CAD, Archief van de staf van de 2e Inf. Brig. Groep, GG 12.
8 R.B. Cribb, 'Jakarta in the Indonesian revolution, 1945-1949' (niet uitgegeven procfschrift London,
1984) 180-184. 
binnen de Pasoendan en daardoor hun eigen toekomst zouden kunnen verzekeren. ${ }^{9}$

Bavinck bracht zijn idee voor het gebruik van de lasykar half mei 1947 naar voren bij de legercommandant, luitenant-generaal S.H. Spoor. Spoor achtte het een aantrekkelijk plan, want de lasykar konden werk verrichten, waarvoor de Nederlandse troepen minder geschikt waren. Politiek vond hij het voorstel ook attractief. Het bestaan van een dergelijke Indonesische hulpeenheid zou duidelijker maken dat de Nederlands-Indische regering terecht stelde dat de door haar voorgestane geleidelijke dekolonisatie van Indonesië steun genoot bij een aanzienlijk gedeelte van de bevolking. Nog belangrijker was echter dat door een lasykar eenheid in te zetten het aantal slachtoffers onder de dienstplichtingen van de 7 December divisie zou verminderen. Na overleg met de procureur-generaal, mr H.W. Felderhof, over het verlenen van voorlopige juridische onschendbaarheid aan de lasykar wat betreft hun optreden in Djakarta in de woelige maanden na de oorlog, werd het voorstel van Bavinck goedgekeurd. Bavinck kreeg financiële ruimte om de lasykar van uniformen, lichte infanteriewapens, soldij en voedsel te kunnen voorzien. Hij gaf zijn nieuwe eenheid de naam Hare Majesteits Ongeregelde Troepen, of HAMOTs. ${ }^{10}$

De HAMOTs kregen vanaf half mei een zekere mate van opleiding, voor velen een eerste ervaring met militaire tucht en theorie. Zij bleven actief als spionnen, maar werden ook in toenemende mate ingezet om het smokkelen van wapens, medicijnen en andere militaire goederen te bestrijden. Daar hadden zij een zekere bekwaamheid in, want tijdens hun verblijf in het Krawangse waren zij zelf zeer actief geweest in dat métier. Van een volledige sluiting van de demarcatielijn was trouwens geen sprake, want Batavia zelf kon niet leven zonder invoer van rijst van het omringende platteland. Deze smokkelbestrijding ging hun redelijk goed af, hoewel zij steeds in de verleiding kwamen om zelf weer deel te nemen aan de illegale handel. ${ }^{11}$

Het succes van het HAMOT-project leverde echter ook weer de nodige moeilijkheden op. Ten eerste kwamen er veel lasykar bij het Klender-kamp om zich te melden voor dienst bij de HAMOTs. Begin juni 1947 waren de HAMOTs al driehonderd man sterk. Vele lasykar brachten ook hun familie mee en het Kampoeng Soemoer kampement groeide zo uit tot een dorpje van ruim zeshonderd mensen. Bavincks voorzieningen waren hierop echter niet berekend. Hij beschikte over beperkt onderdak en over slechts zestig matrassen. De gebouwen waren overvol en sommige lasykar moesten onderdak zoeken buiten het kamp. Ook zijn financiële middelen waren ontoereikend. Bavinck kon alleen maar rijst van inferieure kwaliteit kopen, zodat de HAMOTs die gewend waren goede Krawangse rijst van de bevolking te vorderen, de rijst van Bavinck weigerden. Het HAMOT-project kreeg in toenemende mate het karakter van een uit zijn krachten gegroeide, slecht geoutilleerde sociale inrichting. ${ }^{12}$

9 Yong Mun Cheong, H.J. van Mook and Indonesian independence: a study of his role in DutchIndonesian relations, 1945-48 ('s-Gravenhage, 1982) 105-107; 'Partai Ra'jat Pasundan', (ca. mei 1947), in: ARA, Procgen, inv.no. 3; NEFIS, Verkort politiek situatie-overzicht van Nederlandsch Indië, nr. 11 (mei 1947 ) en nr. 12 (4 juni 1947), in: ibidem; NEFIS, Verkort politiek situatie-overzicht van NederlandschIndië, nr. 14 (s.a. [juni 1947]), in: ARA, Procgen, inv.no. 142; Oorlogsdagboek 2e Inf Brig I Div, 21 mei 1947, in: CAD, Archief staf 2e Inf. Brig. Groep, GG 7; Het dagblad (1 mei 1947); A.H. Nasution, Sekitar Perang Kemerdekaan Indonesia (11 dln; Bandung, 1977) IV, 451.

10 Oorlogsdagboek 3-9 RI, mei-juni 1947, in: CAD, Archief staf 2e Inf. Brig. Grcep, GG 12. Interview luitenant-kolonel b.d. K. Bavinck, 's-Gravenhage, 14 februari 1984.

11 Buurman van Vreeden aan Spoor, 11 juni 1947, in: CAD, HKGS NOI, GG 18 (1947) 7158 ongen.

12 Ibidem; Staf 2e Inf. Brig. Groep, Commandant (kolonel Uylenburg) aan Buurman van Vreeden, 9 juni 1947; Algemeen Hoofdkwartier, afdeling K. \& P. aan Buurman van Vreeden, 11 juni 1947, in: CAD, HKGS NOI, GG 18 (1947) 7158-676; 
Bezwaarlijker voor de Nederlandse autoriteiten was dat de lasykar nog steeds de bevolking in de bezette gebieden plunderden. Met zoveel lasykar in de omgeving van Kampoeng Soemoer konden hun activiteiten nauwelijks worden gecontroleerd. Bovendien liep het Nederlandse leger het risico dat het optreden van de HAMOTs langs en aan de overkant van de demarcatielijn als een schending van het voor de Linggadjati-overeenkomst afgekondigde militaire bestand zou worden beschouwd. Dit zou de positie van de Nederlandse onderhandelaars verzwakken, die de bestandsschendingen van de Republikeinse strijdkrachten langs de demarcatielijn aan de kaak stelden als bewijs dat de Republiek onmachtig of onwillig was om het Linggadjati-akkoord uit te voeren.

Onder zulke omstandigheden vormde het bericht in juni 1947 dat er nog een tweetal bendes gereed stond zich te melden als HAMOTs, voor de Nederlandse legerleiding aanleiding om de HAMOTs als zodanig op te heffen. Van een afzonderlijke gevechtsgroep zou geen sprake meer zijn: een dertigtal lasykar zou worden aangehouden voor spionage en eventuele sabotage, de overige HAMOTs zouden worden bedankt met recht op rantsoen voor een paar weken. Zover is het echter niet gekomen. Omdat het in de loop van juni steeds waarschijnlijker werd dat er een militaire actie tegen de Republiek zou worden ondernomen, besloot de Nederlandse legerleiding eind juni 1947 de eenheid te laten voortbestaan en zelfs verder op te leiden, zij het dat de eenheid werd ingekrompen tot 75 man. Deze kregen een aanvullende militaire opleiding onder toezicht van Bavinck zodat zij als hulptroepen konden optreden. Begin juli 1947 was hun aantal weer opgelopen tot 120 man. ${ }^{13}$

\section{HAMOTs in de eerste politionele actie}

Omstreeks twaalf uur in de nacht van 20 op 21 juli 1947 hernam luitenant gouverneur-generaal H.J. van Mook zijn 'vrijheid van handelen' en begon de zogeheten eerste politionele actie. Terwijl het Korps Speciale Troepen van kapitein R.P.P. Westerling de Republikeinse vertegenwoordigers in Djakarta arresteerde, staken de HAMOTs de demarcatielijn bij Tamboer over. De bedoeling was niet alleen de Republikeinse frontlijn te doorbreken, maar zo mogelijk de grote bruggen over de Tjitjaroemrivier bij Krawang onbeschadigd te veroveren. De Republikeinse legerleiding in West-Java had al lang geleden een plan ontworpen om zich oostwaarts terug te trekken achter de lijn Garoet-Cheribon. Tijdens deze terugtocht zou de verschroeideaardetactiek moeten worden toegepast om de opmars van de Nederlandse troepen te vertragen. Ook de bruggen over de Tjitjaroem waren opgenomen in de Republikeinse vernietigingsplannen. Door hun inlichtingenactiviteiten wisten de Nederlanders van dit Republikeinse voornemen. De HAMOTs hadden tot taak dit te voorkomen en moesten snel langs de grote weg in de richting Krawang doorstoten. Aan de demarcatielijn zelf ondervonden zij weinig weerstand. Na de gevechten in het Krawangse was het Republikeinse leger namelijk nauwelijks nog in staat het

13 Commandant 3-9 RI, 'Geschiedenis HAMOT', 20 juni 1948, in: CAD, Archief staf 2e Inf. Brig. Groep, GG 7; Oorlogsdagboek 3-9 RI, juni en juli 1947, in: ibidem; NEFIS, Verkort politiek situatieoverzicht van Nederlandsch-Indië, nr. 12 (4 juni 1947), in: ARA, Procgen, inv.no. 3; Dagoverzicht van de plaats gehad hebbende geheurtenissen 12, 12 mei 1947, in: ARA, Procgen, inv,no. 147/1; S.L. van der Wal ed., Officiële bescheiden betreffende de Nederlands-Indonesische betrekkingen 1945-1950 (... dln; 's-Gravenhage, 1971-...) IX, 213 en X, 645 noot 2; A. van Sprang, Wij werden geroepen: de geschiedenis van de 7 December Divisie ('s-Gravenhage, 1949) 57; A. van Sprang, Laatste acte: een cocktail van soldatenleven en politiek in Indonesië ('s-Gravenhage, 1947) 23-24; Ra'jat (Jakarta), 29 mei 1947; Interviews met: Sidik Samsi, Jakarta, 11 oktober en 17 november 1982; Abdul Karim Abbas, Jakarta, 30 oktober 1982; K.H. Hasboelah, Klender, 19 oktober 1982; Camat Nata, Cibitung, Bekasi, 26 januari 1983; Hasjim K. Notokoesoemo, Jakarta, 11 november 1982; Kusnandar Partowisastro, 20 januari en 3 februari 1983. 
oostfront van Djakarta te verdedigen. Een Batakse artillerie-eenheid, Beruang $\mathrm{Me}$ rah (de Rode Baren) geheten, stond vlak tegenover het grenscontrolepunt, maar die eenheid had nog maar weinig gevechtswaarde, vanwege hun enthousiaste deelname in de smokkelhandel over de demarcatielijn. De Republikeinen maakten hier zelf het grapje over dat Beruang Merah eigenlijk betekende beruang merah ofwel rood, d.w.z. Nederlands, geld hebbend.

$\mathrm{Na}$ de Beruang Merah uiteen te hebben geslagen, reden de HAMOTs snel door in hun met zandzakken beschermde jeeps om de Republikeinse wachten bij de verschillende stations langs de spoorweg uit te schakelen. Vanuit Klender vertrok tegelijkertijd een gepantserde trein vol Nederlandse troepen om het optreden van de HAMOTs te steunen, munitie aan te voeren en eventueel tegen grotere Republikeinse eenheden op te treden. Vliegtuigen van de luchtvaartafdeling van het KNIL beschoten voortdurend het gebied rond de bruggen over de Tjitjaroem om te vermijden dat de mijnen die al onder de brug lagen, zouden kunnen worden gedetoneerd. In de namiddag van 21 juli kwam de gepantserde trein onder begeleiding van de HAMOTs veilig aan op de oostelijke oever van de Tjitjaroem. Te laat kreeg iemand aan Republikeinse zijde het idee om met een lege locomotief de pantsertrein te rammen. De botsing vond plaats toen de trein al leeg op de oostelijke oever bij de rivier stond. ${ }^{14}$

De HAMOTs waren verder in de politionele actie niet erg actief. Het gebied ten westen van Krawang was hen nagenoeg onbekend. Na de val van Krawang op 22 juli ondervonden de Nederlandse troepen trouwens niet veel tegenstand meer. Vóór het staakt-het-vuren bevel van 4 augustus 1947 hadden de Nederlandse troepen dan ook geheel West-Java, behalve Bantam, veroverd, alsmede aanzienlijke delen van Midden- en Oost-Java en Sumatra. Troepen van de 7 December divisie beheersten dus de gehele Krawangvlakte. De meeste officiële Republikeinse strijdkrachten trokken terug naar Midden-Java of naar de bergachtige gebieden rond Madjalengka, ten zuiden van Cheribon en rond Garoet en Tasikmalaja, volgens de nieuw ontworpen guerrilla-strategie van Nasution. Er bleven echter in het Krawangse nog veel kleinere autonome eenheden achter: uiteengeslagen lasykar eenheden en onafhankelijke gevechtsbenden. Deze stonden een algeheel herstel van de rust in het bezette gebied in de weg.

\section{De activiteiten van de HAMOTs na de eerste politionele actie}

Door hun prestaties tijdens de politionele actie nam de waardering voor de HAMOTs aan Nederlandse zijde enorm toe. Bavinck zelf werd onderscheiden met de Militaire Willemsorde der vierde klasse vanwege zijn activiteiten bij het oprollen van de bende van haji Panji en het oprichten en leiden van de HAMOTs. Andere Nederlandse bataljons volgden zijn voorbeeld en richtten hun eigen Indonesische hulpeenheden op. In Bavincks bataljon verwachtte men ook veel van de HAMOTs bij de verdere zuivering van het Krawangse. Ten behoeve van die pacificatie vormde Bavinck een nieuw hulpkorps uit oud-lasykar en gevangen Republikeinse militairen. De HAMOTs nieuwe stijl telden zes pelotons die te zamen twee- tot driehonderd man telden. Zij werden niet alleen zoals voor de politionele actie voor bewakings- en inlichtingenwerk

14 Nasution, Sekitar Perang Kemerdekaan Indonesia, V, 107, 118-127 en 159-170; VI, 266-271, 338; K. Helder, Tiga Doeabelas: Gedenkboek 3-12 R.I. (Groningen, 1951) 86-89; P. Heijboer, De Politionele Acties: de strijd om 'Indië' 1945/1949 (Amsterdam, 1979) 34-36; Van Sprang, Wij werden geroepen, 77-87; Berita Indonesia, 24, 26 juli 1947. 
gebruikt, maar ook voor het patrouilleren in het gebied. Af en toe 'leende' Bavinck de HAMOTs zelfs uit aan andere Nederlandse legereenheden. ${ }^{15}$

Niet alles liep echter op rolletjes. Panji, die als voormalig lasykarhoofd een belangrijke rol speelde in de HAMOTs naast Bavinck, scheen met de Republikeinse ondergrondse autoriteiten in het Krawangse te hebben onderhandeld. Over zijn motieven is nauwelijks iets bekend. Misschien vond hij de toenemende militaire disciplinering van de HAMOTs onverdragelijk. Misschien zag hij een kans om druk op Bavinck uit te oefenen door diens vrees voor desertie aan te wakkeren. Het is mogelijk, maar niet erg waarschijnlijk, dat hij al lang een dubbelspel speelde om wapens en manschappen te verzamelen voor toekomstig verzet tegen de Nederlanders. Volgens Bavinck werd hij toen men zijn verraad in augustus 1947 ontdekte, opgepakt en doodgeschoten. Terwille van het moreel van de HAMOTs werd echter door 3-9 RI een andere lezing van Panji's dood gegeven. Het heette dat Panji was ontvoerd en vermoord door de TNI. 16

Panji's gedrag was echter een teken van toenemende ontevredenheid onder de HAMOT. Na de Nederlandse verovering van de Krawangvlakte namen de militaire plichten van de HAMOTs sterk toe. De tactiek van 3-9 RI in Klender waar het door intensief te patrouilleren en snel te reageren de veiligheid van zijn Indonesische medewerkers redelijk kon garanderen, kon niet succesvol worden toegepast in het veel grotere en onbekende gebied waar 3-9 RI na de politionele actie verantwoordelijk voor was. Om de toestand enigszins onder controle te krijgen heeft 3-9 RI de HAMOTs op grote schaal ingezet. Het was vermoeiend en gevaarlijk werk. In de eerste twee en een halve maand na de politionele actie verloren vijftig HAMOTs het leven. De levensstijl van het Djakartaanse bendewezen bood de lasykar nooit veel uitzicht op een vreedzame dood, maar aan deze verliezen waren ook zij niet gewoon. Zelfs met hulp van het Depot Speciale Troepen, dat in de maanden augustus en november 1947 meerdere malen optrad in het Krawangse, konden de Nederlandse troepen de toestand niet meester worden. Half november 1947 moest 3-9 RI zelfs het gehele noordelijke gedeelte van zijn gebied, een uitgestrekte streek ten noorden van het irrigatiekanaal Tjikampek-Kosambi, ontruimen..$^{17}$

Geruchten over een toekomstig terugtrekken van de Nederlandse troepen, zoals vastgelegd in de Linggadjati overeenkomst bleven de ronde doen. De Nederlandse overwinning van juli 1947 nam snel de geur aan van een nederlaag. De lasykar die altijd primair aan hun eigen toekomst dachten, bekeken de situatie althans zo en waren niet genegen om met de Nederlanders ten onder te gaan. Individuele deserties namen toe en in de nacht van 26 op 27 november verliet een geheel HAMOT-peloton zijn post met meedeneming van hun geweren en een mortier. De Nederlandse

15 Berita Indonesia, 27-28 augustus 1947; 'Inheemse vrijwilligers 2e Inf Brig Groep', 2 juni 1948, en 'Geschiedenis HAMOT', 20 juni 1948, Oorlogsdagboek staf 2e Inf Brig. Groep, in: CAD, archief staf 2e Inf. Brig. Groep, GG 10, map XII, bijlage 11; in: CAD, Archief staf 2e Inf. Brig. Groep, GG 7; Staf 2e Inf Brig Groep, afd. Operatiën, 'Voorstel org. Laskar-Rajat-eenheden', 28 november 1947, in: CAD, HKGS NOI, GG 18 (1947) 7158; Rapport over het bezoek aan het 'hervormingsinstituut' van de tlnt K. Bavinck te Tjikampek op 6 en 7 oktober 1947, in: ARA, Archief Algemene Secretarie, I III-30-13; ANETA-Nieuws (4 augustus 1948). Interview met luitenant-kolonel b.d. K. Bavinck, 's-Gravenhage, 14 februari 1984.

16 Oorlogsdagboek 3-9 RI, 15 augustus 1947, in: CAD, Archief Staf 2e Inf. Brig. Groep. GG 12. Berita Indonesia, 24 september 1947; Interview met luitenant-kolonel b.d. K. Bavinck, 's-Gravenhage, 14 februari 1984; vertrouwelijk interviews met voormalige lasykar.

17 Oorlogsdagboek 3-9 RI, 15 augustus t/m november 1947, in: CAD, Archief Staf 2e Inf. Brig. Groep, GG 12. Rapport nr 13 (Tjileoengsir and Klapanoenggal), 5-7 februari 1948, in: ARA, Archief MichielsArnold-Landen, inv.no. 110; J.A. de Moor, 'Het Korps Speciale Troepen: tussen Marechaussee formule en Politionele Actie', in: G. Teitler en P.M.H. Groen, ed., De Politionele acties (Amsterdam, 1987) 129-131; Heijboer, Politionele acties, 115-116. 
korporaal die het pelotonscommando voerde, sliep tijdens de desertie door en stond eenzaam, maar levend en zonder twijfel nogal opgelucht, de volgende ochtend op. ${ }^{18}$

\section{Het einde van de HAMOTS}

Het einde voor de HAMOTs kwam met de plannen van de Nederlandse legertop om 3-9 RI te verplaatsen. De militaire autoriteiten wisten weliswaar dat niemand de plaats van Bavinck zou kunnen innemen, wiens charismatische persoonlijkheid en persoonlijke kwaliteiten van essentieel belang waren voor de bruikbaarheid van de HAMOTs, maar een dergelijke erkenning paste niet in de moderne legervorming. Bovendien zou 3-9 RI te gelegenertijd weer dienst moeten doen in Europa en daarbij zou geen taak of plaats zijn voor HAMOTs. Van onmiddellijke ontbinding van de HAMOTs was eind 1947 nog geen sprake, maar hun toekomst werd toen al onzekerder. De HAMOTs zagen het ook als een teken aan de wand dat enkele strijdmakkers die op verlof in Djakarta waren alsnog werden gearresteerd vanwege moord en diefstal in 1945 . De eerder toegezegde voorlopige wettelijke onschendbaarheid van de HAMOTs werd plotseling opgeheven en nog meer lasykar deserteerden dientengevolge naar de Republikeinse 'pockets' in het gebergte van West-Java. Door deze gebeurtenissen verloren de HAMOTs ook hun eventuele kansen om te worden opgenomen in de nieuwe veiligheidsbataljons van de Negara Pasoendan. De wervers voor de veiligheidsbataljons gaven de voorkeur aan individuele werving van bekwame mensen en wezen inlijving van bestaande, maar onbetrouwbare groepen lasykar af. 3-9 RI verliet Krawang midden 1948. Hun plaats werd door KNIL-eenheden ingenomen en de resterende HAMOTs werden naar Semarang overgeplaatst om op kleine schaal bewakingstaken en dergelijke uit te voeren. Van hun lot na de soevereiniteitsoverdracht is weinig bekend, maar men neemt aan dat zij verstandig genoeg waren om in de richting van Krawang te verdwijnen. ${ }^{19}$

De HAMOTs hebben een belangrijke rol gespeeld in de poging van Nederland om zijn gezag in Indonesië te herstellen. De Nederlandse regering ging in juli 1947 en december 1948 over tot de politionele acties in de veronderstelling dat rust en orde gewapenderhand hersteld konden worden. De rol van de HAMOTs bij de succesvolle pacificatie van Klender vóór de eerste Politionele Actie en van het Krawangse daarna, droeg er toe bij dat de Nederlands-Indische leger- en regeringstop geloof had in de goede afloop van zijn militair ingrijpen. Het voorbeeld van Klender was echter slechts schijn. Weliswaar gebruikten de Nederlandse strijdkrachten andere Indonesische hulptroepen na de tweede Politionele Actie, zoals de ondernemingswachten en de veiligheidsbataljons, maar zij waren niet in staat om zich meester te maken van het Javaanse platteland.

In een wereld van modern opgeleide legereenheden waren de HAMOTs een anachronisme. Men of violence die liefst als vrijbuiters optraden, konden zich met moeite aan de moderne militaire organisatie aanpassen en deze op zijn beurt kon hen slechts met moeite opnemen. Toch werkten de omstandigheden een samenwerking in de hand. De lasykar wilden hun toekomst redden in een onafhankelijk Indonesië, waarvan zowel de vorm als de inhoud nog onduidelijk was. Het Nederlandse leger wilde niet alleen een militaire overwinning behalen, maar ook het Indonesische element in hun strijdmacht versterken en benadrukken. De onwaarschijnlijke coalitie is uiteindelijk uiteengevallen, maar niet voordat zij een rol heeft gespeeld in de moeilijke terugtocht van het Nederlands gezag uit Indonesië.

18 Van Sprang, Wij werden geroepen, 122; Dagelijks operatief rapport 27 nov 1947, Oorlogsdagboek 3-9 RI. Interview met luitenant-kolonel b.d. K. Bavinck, 's-Gravenhage 14 februari 1984.

19 Interview met luitenant-kolonel b.d. K. Bavinck, 's-Gravenhage, 14 februari 1984. 


\section{'De onverbloemde waarheid'. \\ De interne voorlichting aan militairen over Indonesië, 1945-1950}

\section{F. Imandt}

Nederland raakte na de Tweede Wereldoorlog vrijwel meteen betrokken bij een volgende oorlog, namelijk die in Indonesië. De uitroeping van de Republiek door de Indonesische nationalisten Soekarno en Hatta op 17 augustus 1945, twee dagen na de Japanse capitulatie, werd door Nederland op dat moment niet erkend en gedurende vier jaar fel bestreden, zowel met politieke als militaire middelen. Naarmate Nederland meer verstrikt raakte in het koloniaal conflict, voelde de Nederlandse regering steeds sterker de behoefte om zowel de Nederlandse en Indonesische bevolking als de uit te zenden militairen en het buitenland voor te lichten.

Tijdens de Tweede Wereldoorlog was er door sommigen binnen de Nederlandse regering en militaire leiding in ballingschap al gedacht en gesproken over de noodzaak na de oorlog voorlichting over de Nederlandse regeringspolitiek te geven, zij het met terughoudendheid, want voor grote delen van de bevolking had voorlichting een propagandistische bijsmaak. I In feite moest Nederland in mei 1945 wat overheidsvoorlichting betreft van de grond af beginnen, terwijl de behoefte aan informatie alsmaar groeide. Leger- en marinevoorlichting was zo mogelijk een nog onbekender instrument voor zowel de militaire leiding als de regering, terwijl een goed beleid in deze, gezien het feit dat Nederland nooit eerder zo'n omvangrijke troepenmacht op de been had gebracht als in de periode 1945-1950, juist een eerste vereiste was. Toen in 1946 bekend werd dat naast oorlogsvrijwilligers (OVW-ers) ook dienstplichtigen zouden worden uitgezonden, kwam de legervoorlichting organisatorisch en beleidsmatig in een stroomversnelling. De militairen die naar Indonesië gingen, merkten daar echter weinig van en hadden dan ook veel kritiek op de voorlichting, of liever gezegd het gebrek daaraan.

In dit artikel wordt een overzicht gegeven van wat er op het gebied van krijgsmachtvoorlichting tot stand is gebracht in de periode 1945-1950. In het eerste gedeelte komen de verschillende instanties die zich met voorlichting binnen de krijgsmacht bezighielden aan de orde. Daarna worden de voorlichtingsmiddelen behandeld en het volgende deel zal ingaan op de problemen die de regering en de legerleiding hadden met de beleidsontwikkeling op het gebied van de krijgsmachtvoorlichting. Als laatste onderdeel komt kort het effect van de voorlichting, en dan met name op het moreel van de troepen, aan bod.

\section{De voorlichtingsorganen}

Binnen de Nederlandse krijgsmacht hield een aantal instanties zich met interne voorlichting, dat wil zeggen voorlichting aan militairen, bezig. In Den Haag waren dat de Legervoorlichtingsdienst (LVD) en de Marine- en de Luchtmachtvoorlichtingsdienst (Marvo en Luvo). De Dienst Leger Contacten (DLC) was gevestigd in Djakarta. Niet-krijgsmachtgebonden organisaties zoals de Regeringsvoorlichtingsdienst (RVD) en verschillende belangenorganisaties, zoals de Nationale

${ }_{1}$ Overheidsvoorlichting. Rapport der adviescommissie overheidsbeleid inzake voorlichting ingesteld 6 maart 1946 ('s-Gravenhage, 1946) 7. 